\title{
KAJIAN TIGA RUMUS ANGKUTAN SEDIMEN MELAYANG SUNGAI SERAYU DIBANDINGKAN DENGAN HASIL LABORATORIUM
}

\author{
Reynaldo $^{1}$, Wati Asriningsih Pranoto ${ }^{2}$ \\ ${ }^{1}$ Program Studi Sarjana Teknik Sipil, Universitas Tarumanagara, Jl. Letjen S. Parman No.1 Jakarta \\ Email: reynaldokristianjayakusuma@gmail.com \\ ${ }^{2}$ Ketua Program Studi Magister Teknik Sipil, Universitas Tarumanagara, Jl. Letjen S. Parman No.1 Jakarta \\ Email: watip@ft.untar.ac.id
}

\begin{abstract}
ABSTRAK
Sungai Serayu adalah salah satu sungai terpanjang di pulau jawa dengan panjang sungai utama mencapai $180 \mathrm{~km}$. Sungai Serayu mempunyai debit aliran yang cukup besar sehingga dapat membawa berbagai ragam partikel hasil dari erosi. Penelitian akan berfokus pada angkutan sedimen melayang (suspended load). Penelitian akan dilakukan di lLaboratorium dan akan dibandingkan dengan pendekatan rumus Einstein's ; Lane dan Kalinske's ; Chang, Simon dan Richardson's. Penelitian Laboratorium dikakukan pada sirkular flum menggunakan sampel berupa lumpur yang diambil pada muara Sungai. Hasil percobaan Laboratorium menghasilkan kisaran debit angkutan sedimen melayang sebesar $0.0004-0.0014 \mathrm{~kg} / \mathrm{s} / \mathrm{m}$ dari debit air $0.0022-0.0031 \mathrm{~m}^{3} / \mathrm{s}$. Dari ke-3 pendekatan rumus, yang paling mendekati dengan hasil Laboratorium adalah pendekatan Chang, Simon, and Richardson's.
\end{abstract}

Kata kunci: debit angkutan sedimen melayang, Sungai Serayu.

\section{PENDAHULUAN}

\section{Latar belakang}

Sungai merupakan jaringan alur-alur pada permukaan bumi yang terbentuk secara alamiah, mulai dari bentuk kecil dibagian hulu sampai besar dibagian hilir. Aliran sungai merupakan sumber air yang paling dominan untuk memenuhi kebutuhan hidup manusia . (Sudira I W., 2013)

Indonesia sendiri memiliki 5.590 sungai utama, salah satunya adalah Sungai Serayu. Sungai Serayu merupakan salah satu sungai terbesar di Pulau Jawa yang terletak di Provinsi Jawa Tengah yang melintasi beberapa kabupaten, seperti Kabupaten Wonosobo, Banjarnegara, Purbalingga, Banyumas dan Cilacap. Panjang sungai utama mencapai 180km dengan 11 anak sungai. (Balai Besar Wilayah Sungai Serayu-Opak, 2016)

Dalam proses angkutan sedimen di sungai akan terbagi menjadi dua jenis angkutan sedimen, yaitu angkutan sedimen dasar (bed load transport) dan angkutan sedimen melayang (suspended load transport). Banyaknya sedimen yang terangkut akibat aliran air sungai ditentukan oleh kecepatan aliran. Selain dipengaruhi oleh kecepatan aliran, angkutan sedimen melayang (Suspended Load Transport) dipengaruhi juga oleh panjang sungai, kemiringan dasar sungai, luas penampang sungai, kedalaman sungai dan beberapa parameter lainnya yang berpengaruh terhadap proses angkutan sedimentasi.

Hasil angkutan sedimen dari aliran Sungai Serayu dapat diperoleh dengan melakukan percobaan pengangkutan sedimen di laboratorium. Dengan percobaan kecepatan aliran yang beragam sehingga akan menghasilkan volume sedimen percobaan yang bervariasi sesuai dengan kecepatan aliran yang dicoba.

Beberapa ahli sudah mengemukakan rumus untuk mencari debit angkutan sedimen melayang, yaitu Einstein's ; Lane dan Kalinske's ; Chang,Simon dan Richardson's.

\section{Identifikasi masalah}

Untuk melakukan perhitungan debit angkutan sedimen melayang (qs) ada dua cara yang dapat dilakukan. Pertama dengan melakukan percobaan di Laboratorium dan kedua dengan menggunakan pendekatan rumus yang terlah dikemukakan oleh beberapa ahli. Sehubungan dengan masalah sedimentasi yang terjadi di Sugai Serayu, pendekatan rumus yang akan digunakan untuk menghitung debit angkutan sedimen melayang adalah pendekatan Einstein's; Lane and kalinske's; Chang, Simon and Richardson's. Perhitungan dengan menggunakan pendekatan rumus tentu saja akan ada kekurangan dan lebihnya, oleh karena itu diperlukan analisis perbandingan hasil percobaan di Laboratorium dengan hasil perhitungan pendekatan rumus sehingga dapat ditentukan pendekatan rumus mana yang lebih tepat untuk digunakan. 


\section{Batasan masalah}

Batasan masalah pembahasan yang dianalisa yaitu :

1. Studi hanya difokuskan pada angkutan sedimen melayang Sungai Serayu.

2. Analisa dilakukan dengan percobaan di laboratorium Hidrolika dan laboratorium Mekanika Tanah.

3. Pendekatan atau rumus yang digunakan hanya dengan pendekatan Einstein's; Lane and kalinske's; Chang, Simon and Richardson's.

\section{Rumusan masalah}

Rumusan masalah yang dikemukakan pada penelitian ini diantaranya adalah :

1. Bagaimana debit angkutan sedimen melayang (qs) Sungai Serayu dengan beberapa variasi kecepatan pada studi laboratorium ?

2. Bagaimana hasil debit sedimen melayang (qs) berdasarkan pedekatan Einstein's; Lane and kalinske's; Chang, Simon and Richardson's ?

3. Bagaimana Perbandingan antara hasil laboratorium dengan hasil pendekatan rumus ?

\section{Tujuan penelitian}

Tujuan dari penelitian ini adalah:

1. Untuk memperoleh debit angkutan sedimen melayang (qs) Sungai Serayu dengan beberapa variasi kecepatan.

2. Untuk mendapatkan debit angkutan sedimen melayang (qs) dengan rumus pendekatan Einstein's; Lane and kalinske's; Chang, Simon and Richardson's.

3. Untuk memperoleh perbandingan debit angkutan sedimen melayang (qs) berdasarkan hasil laboratorium dengan hasil pendekatan rumus.

\section{DASAR TEORI}

\section{Erosi dan Sedimentasi}

Erosi adalah suatu proses pengikisan yang bisa disebabkan oleh angin dan aliran air yang terjadi pada batuan yang mengalami pelapukan. Sedimentasi merupakan proses pengangkutan dan pengendapan material tanah pada sungai yang diakibatkan oleh faktor erosi. Erosi yang terjadi di hulu sungai akan menyebabkan terjadinya sedimentasi di hilir sungai. Partikel-partikel tanah atau material lainnya yang jatuh ke sungai akan terbawa oleh aliran sungai. (Pratiwi Y., 2014)

Suatu proses sedimentasi pada umumnya diakibatkan oleh 2 faktor utama, yaitu air dan angin. Kedua faktor ini yaitu siklus hidrologi maupun perputaran angin sangat berpengaruh pada proses sedimentasi. Sebesar $2 / 3$ bagian dari proses presipitasi air (hujan) terjadi di daratan dan kembali ke atmosfir melalui proses evaporasi dan transpirasi. Sisanya mengalir kembali ke laut dalam bentuk aliran sungai, aliran pada permukaan daratan sebagai aliran run-off dan ada yang meresap ke dalam tanah sebagai air tanah. Jumlah air actual yang terlibat akan berbeda-beda dari setiap tempat. Perbedaan jumlah air dipengaruhi oleh kondisi geografi dan iklim tetapi juga dipengaruhi juga oleh seberapa besar muatan air yang tersedia. (Sengupta S.M., 1994).

Dari hasil siklus hidrologi, air hujan yang jatuh akan menghasilkan aliran air di sungai yang akan mengalir dari tempat tinggi ke rendah (dari hulu ke hilir). Aliran sungai ini akan membawa sedimen yang terlarut maupun yang tidak terlarut akibat pelapukan batuan yaitu berupa partikel-partikel tanah. Partikel-partikel yang sudah terbawa masuk ke dalam aliran sungai akan mengalami proses angkutan sedimen.

Air juga berpengaruh besar pada proses pelapukan, dan pembentukan sebagian besar batuan metamorf dan batuan beku. Jumlah hasil sedimentasi tidak hanya bergantung dari proses presipitasi (hujan) yang ada dalam siklus hidrologi, tetapi ada faktor-faktor lain yang mempengaruhi hasil sedimentasi. Faktor tersebut adalah dari kondisi permukaan daratan, jenis batuan yang terpapar maupun tertutup oleh vegetasi, dan dapat terjadi pula melalui proses mekanis, kimia, dan biologi. (Sengupta S.M., 1994).

\section{Analisa Saringan}

Ada beberapa teknik umum untuk menentukan ukuran gradasi butiran, yaitu (I) pengukuran langsung dengan macro ataupun mikroskop, (II) dengan menggunakan analisa saringan (sieve analysis), dan (III) dengan pengendapan. Analisa saringan digunakan untuk menentukan ukuran butiran dari yang agak besar sampai pasir halus (fine sand). Untuk menentukan diameter butiran seperti lanau dan lempung harus menggunakan metode pengendapan agar mengetahui ukuran diameter sampel yang mendominasi. (Sengupta S.M., 1994) 
Menurut Wenworth (1992) berikut adalah kategori ukuran diameter partikel sesuai dengan diameternya (Tabel 1. Klasifikasi butiran). Setiap Butiran akan diklasifikasikan berdasarkan dengan ukuran diameter butirannya yang lolos pada nomor saringan dengan diameter tertentu.

Tabel 1. Kalsifikasi Butiran (Wentworth, 1992)

\begin{tabular}{|c|c|c|}
\hline & Nama Partikel & Diameter Partikel $(\mathrm{mm})$ \\
\hline \multirow{4}{*}{ Kerikil } & Boulders & $>256$ \\
\hline & Cobbles (bongkah) & $64-256$ \\
\hline & Pebbles (kerikil) & $4-64$ \\
\hline & Granules (butir) & $2-4$ \\
\hline \multirow{7}{*}{ Pasir } & $\begin{array}{l}\text { Very coarse sand (sangat } \\
\text { kasar) }\end{array}$ & $1-2$ \\
\hline & Coarse sand (kasar) & $0,5-1$ \\
\hline & Medium sand (sedang) & $0,25-0,5$ \\
\hline & Fine sand (halus) & $0,125-0,25$ \\
\hline & $\begin{array}{l}\text { Very find sand (sangat } \\
\text { halus) }\end{array}$ & $0.0625-0,125$ \\
\hline & Lanau (silt) & $0,004-0,0625$ \\
\hline & Lempung (clay) & $<0,004$ \\
\hline
\end{tabular}

\section{Angkutan Sedimen Melayang (Suspended Load Transport)}

Sedimen melayang (suspended load) yaitu partikel yang bergerak dalam aliran yang cenderung terus menerus melayang bersama aliran. Muatan sedimen layang bergerak bersama dengan aliran air sungai, terdiri dari pasir halus yang senantiasa didukung oleh air, dan hanya sedikit sekali berinteraksi dengan dasar sungai karena sudah didorong ke atas oleh turbulensi aliran. (Diansari R., 2014)

Yang termasuk dalam sedimen melayang adalah sedimen yang Bersatu Bersama dengan aliran, umumnya ukuran sedimen melayang dimulai dari ukuran 0,062 $\mathrm{mm}$ ke bawah atau di bawah very fine sand, ukuran seidmen melayang akan sulit untuk diukur dengan saringan. (Sengupta S.M., 1994)

Hal yang paling mendasari debit angkutan sedimen melayang adalah besarnya debit air, berikut adalah rumus untuk menghitung debit air dan debit angkutan sedimen melayang.

$$
\begin{gathered}
Q_{\text {air }}=v \times B \times H \\
Q_{s}=Q_{\text {air }} \times(C s: 1000: B)
\end{gathered}
$$

Dengan Cs = konsentrasi sedimen (ppm), $Q_{\text {air }}=$ debit air $\left(\mathrm{m}^{3} / \mathrm{s}\right), \mathrm{v}=$ kecepatan air $(\mathrm{m} / \mathrm{s}), \mathrm{B}=$ lebar saluran (m), $\mathrm{H}=$ tinggi air $(\mathrm{m}), \mathrm{Q}_{\mathrm{b}}=$ debit angkutan sedimen melayang $(\mathrm{kg} / \mathrm{s} / \mathrm{m})$.

\section{Persamaan Debit Angkutan Sedimen Melayang}

Pendekatan rumus yang akan digunakan adalah rumus pendekatan Einstein's ; Lane dan Kalinske's ; Chang, Simon dan Richardson's berikut adalah ke3 rumus pendekatan yang dikemukakan oleh para ahli : 
Einstein's merumuskan angkutan sedimen melayang dengan menggunakan persamaan

$$
\mathrm{q}_{\mathrm{sw}}=11.6 \mathrm{U}^{*} \mathrm{C}_{\mathrm{a}} \mathrm{a}\left\{\left[2.303 \log \frac{30.2 D}{\Delta}\right] \mathrm{I}_{1}+\mathrm{I}_{2}\right\}
$$

Dengan $\mathrm{q}_{\mathrm{sw}}=$ debit angkutan sedimen melayang $(\mathrm{kg} / \mathrm{s} / \mathrm{m}), \mathrm{U}^{*}=$ kecepatan geser, $\mathrm{C}_{\mathrm{a}}=$ konsentrasi sedimen di atas permukaan, $\mathrm{a}=2 \mathrm{x}$ ukuran deiameter sedimen, $\mathrm{D}=$ kedalaman air, $\Delta=$ kedalaman air $/$ faktor koreksi Einstein (gambar 1), $\mathrm{I}_{1} \& \mathrm{I}_{2}=$ numerik intregritas (gambar 2 dan 3 )

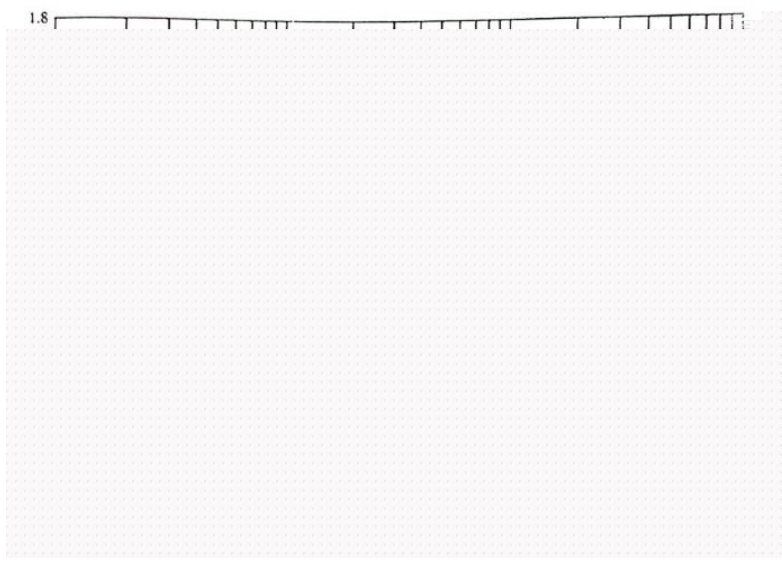

Gambar 1. Faktor Koreksi Einstein's

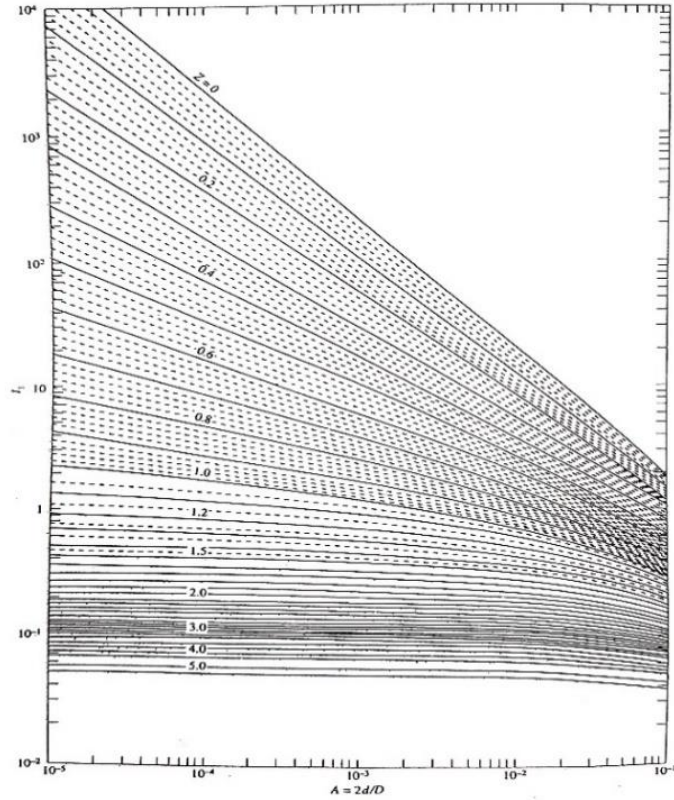

Gambar 2. Nilai $\mathrm{I}_{1}$

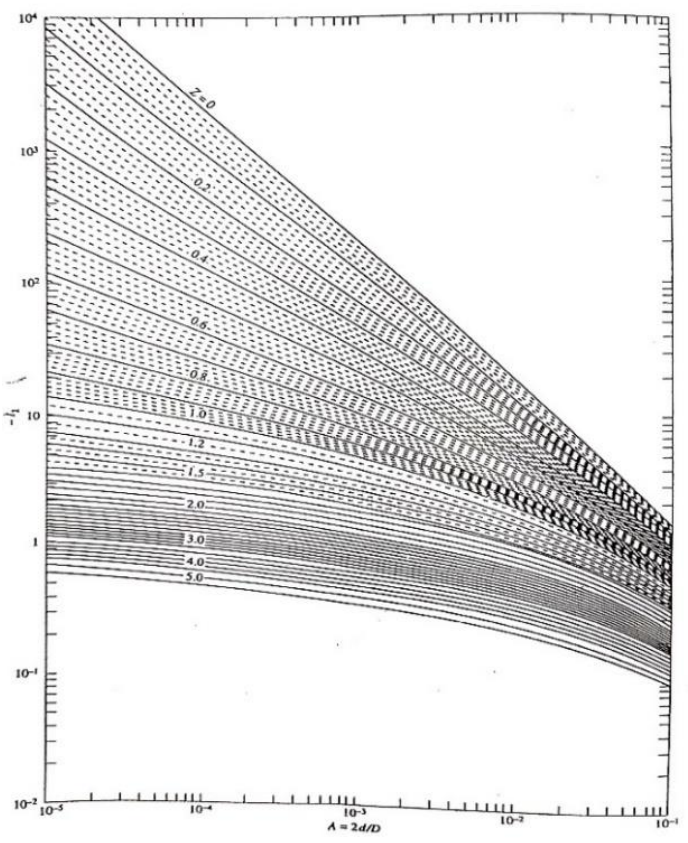

Gambar 3. Nilai $\mathrm{I}_{2}$ 
Lane dan Kalins's merumuskan angkutan sedimen melayang dengan menggunakan persamaan

$$
\mathrm{q}_{\mathrm{sw}}=\mathrm{q}_{\mathrm{a}} \mathrm{P}_{\mathrm{L}} \exp \left(\frac{15 \omega a}{U * D}\right)
$$

Dengan $\mathrm{q}_{\mathrm{sw}}=$ debit angkutan sedimen melayang $(\mathrm{kg} / \mathrm{s} / \mathrm{m}), \mathrm{U}^{*}=$ kecepatan geser, $\mathrm{C}_{\mathrm{a}}=$ konsentrasi sedimen di atas permukaan, $\mathrm{a}=$ tebal bed load, $\mathrm{D}=$ kedalaman air, $\omega=$ kecepatan jatuh sedimen, $\mathrm{P}_{\mathrm{L}}=$ nilai koefisien dari gambar 4. Dan $q=$ debit air.

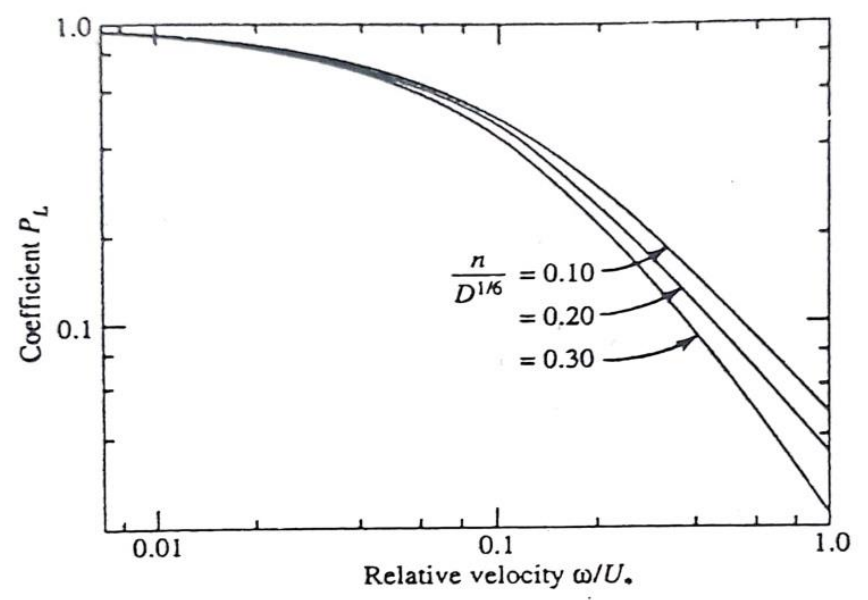

Gambar 4. Nilai Koefisien $\mathrm{P}_{\mathrm{L}}$

Chang, Simon dan Richardson's merumuskan angkutan sedimen melayang dengan menggunakan persamaan

$$
\mathrm{qsw}=\mathrm{D} \text { Ca }\left(\mathrm{VI} 1-\frac{2 U *}{k} \mathrm{I} 2\right)
$$

Dengan $\mathrm{q}_{\mathrm{sw}}=$ debit angkutan sedimen melayang $(\mathrm{kg} / \mathrm{s} / \mathrm{m}), \mathrm{U}^{*}=$ kecepatan geser, $\mathrm{C}_{\mathrm{a}}=$ konsentrasi sedimen di atas permukaan, $\mathrm{D}=$ kedalaman air, $\mathrm{V}=$ kecepatan air, $\mathrm{k}=$ konstanta von karman $(0,4), \mathrm{I}_{1}$ dan $\mathrm{I}_{2}=$ Numerik integritas dari gambar 5 dan 6.

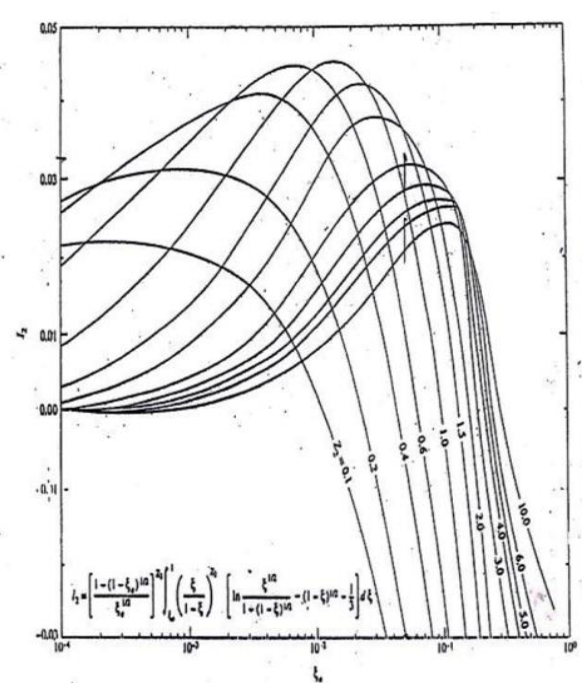

Gambar 5. Nilai $\mathrm{I}_{1}$

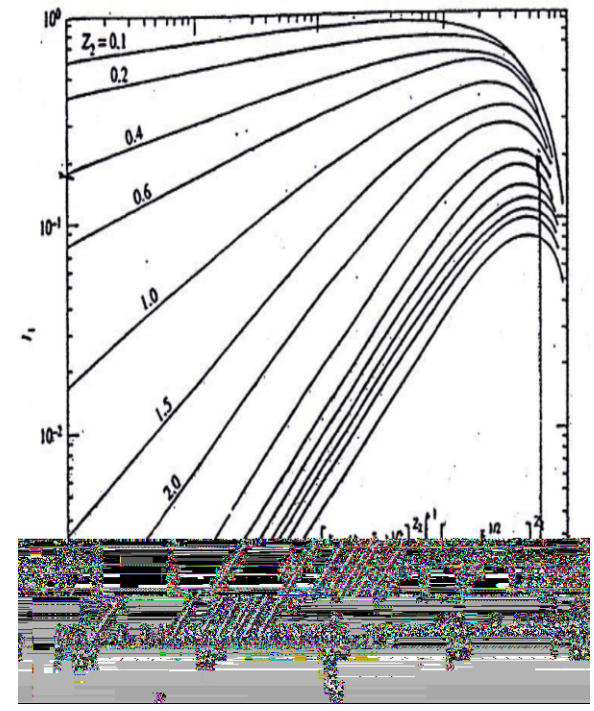

Gambar 6. Nilai $\mathrm{I}_{2}$ 


\section{METODOLOGI PENELITIAN}

\section{Metode Analisis Data}

Sebelum dilakukannya analisis data, dilakukan pembelajaran atau studi tentang teori-teori dasar yang berhubungan dengan topik pembahasan dalam penelitian yang akan dilakukan. Teori dasar yang digunakan sebagai acuan pembelajaran dapat dicari berdasarkan berbagai macam sumber, seperti jurnal, karya ilmiah, buku referensi. Setelah memahami mengenai penelitian ini, dilakukan persiapan sampel lalu melakukan percobaan laboratorium. Kemudian hasil yang didapat dari percobaan laboratorium dibandingkan dengan ketiga pendekatan yaitu pendekatan Einstein's ; Lane dan Kalinske's ; Chang, Simon dan Richardson's.

Untuk jenis sampel yang akan digunakan adalah sampel berupa lumpur yang di ambil dari muara sungai serayu yang akan dipilah menggunakan saringan no.200. Kemudian untuk digunakan dalam perhitungan akan digunakan ukuran butiran yang paling mendominasi hasil dari test hidrometer.

\section{ANALISIS DAN PEMBAHASAN}

\section{Hydrometer test}

Dalam penelitian ini dilakukan percobaan di laboratorium mekanika tanah untuk mengetahui ukuran butiran yang paling mendominasi untuk digunakan pada perhitugan. Hasil dari test hydrometer yang akan digunakan pada perhitungan adalah ukuran $0.03161 \mathrm{~mm}$ yang dapat dilihat pada tabel 2 .

Tabel 2. Resume Hydrometer Test

\begin{tabular}{cccc}
\hline Test & $\begin{array}{c}\text { particel diameter } \\
(\mathrm{mm})\end{array}$ & $\begin{array}{c}\text { percent retained } \\
(\%)\end{array}$ & $\begin{array}{c}\text { percent finner } \\
(\%)\end{array}$ \\
\hline \multirow{7}{*}{ Hydro } & 0.0316 & 17.53 & 72.75 \\
\cline { 2 - 4 } & 0.0250 & 10.90 & 61.85 \\
\hline 0.0217 & 7.27 & 54.58 \\
\cline { 2 - 4 } & 0.0198 & 7.27 & 47.32 \\
\cline { 2 - 4 } & 0.0152 & 12.72 & 34.60 \\
\cline { 2 - 4 } & 0.0116 & 7.27 & 27.34 \\
\cline { 2 - 4 } & 0.0085 & 7.27 & 20.07 \\
\cline { 2 - 4 } & 0.0061 & 3.63 & 16.44 \\
\cline { 2 - 4 } & 0.0044 & 1.82 & 14.62 \\
\cline { 2 - 4 } & 0.0031 & 1.82 & 12.81 \\
\hline 0.0022 & 1.82 & 10.99 \\
\hline 0.0013 & 1.82 & 9.17 \\
\hline & 0.0000 & 9.17 & 0.00 \\
\hline
\end{tabular}

\section{Percobaan laboratorium Hidrolika Hasil Percobaan Berdasarkan Debit Air}

Rangkuman hasil uji laboratorium hidrolika berdasarkan debit air dapat dilihat pada Tabel 3 dan tabel 4. Dan grafik perbandingan antara debit air dengan debit angkutan sedimen melayang dapat dilihat pada gambar 7.

Tabel 3. Rekapitulasi Debit Air Dengan Debit Angkutan Sedimen Melayang

\begin{tabular}{|c|c|c|c|c|c|c|c|}
\hline \multicolumn{4}{|c|}{ Sampel 1} & \multicolumn{4}{|c|}{ Sampel 2} \\
\hline Lapisan & Kondisi & $\mathrm{Q}$ air $(\mathrm{m} 3 / \mathrm{s})$ & Qs (kg/m-s) & Lapisan & Kondisi & $\mathrm{Q}$ air $(\mathrm{m} 3 / \mathrm{s})$ & Qs (kg/m-s) \\
\hline \multirow{2}{*}{1} & Awal & 0.0022 & 0.00083 & \multirow[t]{2}{*}{1} & Awal & 0.0022 & 0.00062 \\
\hline & Akhir & 0.0029 & 0.00123 & & Akhir & 0.0030 & 0.00183 \\
\hline 2 & Awal & 0.0022 & 0.00073 & 2 & Awal & 0.0023 & 0.00055 \\
\hline
\end{tabular}




\begin{tabular}{|c|c|c|c|c|c|c|c|}
\hline & Akhir & 0.0030 & 0.00100 & & Akhir & 0.0030 & 0.00106 \\
\hline \multirow{2}{*}{3} & Awal & 0.0023 & 0.00064 & \multirow{2}{*}{3} & Awal & 0.0023 & 0.00071 \\
\hline & Akhir & 0.0030 & 0.00110 & & Akhir & 0.0030 & 0.00138 \\
\hline \multirow{2}{*}{4} & Awal & 0.0023 & 0.00075 & \multirow{2}{*}{4} & Awal & 0.0023 & 0.00044 \\
\hline & Akhir & 0.0031 & 0.00125 & & Akhir & 0.0030 & 0.00086 \\
\hline \multirow{2}{*}{5} & Awal & 0.0024 & 0.00081 & \multirow{2}{*}{5} & Awal & 0.0023 & 0.00046 \\
\hline & Akhir & 0.0031 & 0.00118 & & Akhir & 0.0031 & 0.00135 \\
\hline
\end{tabular}

Tabel 4. Rekapitulasi Debit Air Dengan Debit Angkutan Sedimen Melayang

\begin{tabular}{cccc}
\hline \multicolumn{4}{c}{ Sampel 3 } \\
\hline \multirow{2}{*}{ Lapisan } & Kondisi & $\begin{array}{c}\text { Q air } \\
(\mathrm{m} 3 / \mathrm{s})\end{array}$ & $\begin{array}{c}\text { Qs } \\
(\mathrm{kg} / \mathrm{m}-\mathrm{s})\end{array}$ \\
\hline \multirow{2}{*}{1} & Awal & 0.0022 & 0.00084 \\
\cline { 2 - 4 } 2 & Akhir & 0.0030 & 0.00128 \\
\hline \multirow{2}{*}{2} & Awal & 0.0023 & 0.00064 \\
\cline { 2 - 4 } 3 & Akhir & 0.0030 & 0.00101 \\
\hline \multirow{2}{*}{4} & Awal & 0.0023 & 0.00069 \\
\cline { 2 - 4 } & Akhir & 0.0030 & 0.00192 \\
\cline { 2 - 4 } 5 & Awal & 0.0023 & 0.00052 \\
\hline \multirow{2}{*}{5} & Akhir & 0.0030 & 0.00409 \\
\cline { 2 - 4 } & Awal & 0.0024 & 0.00050 \\
\hline
\end{tabular}

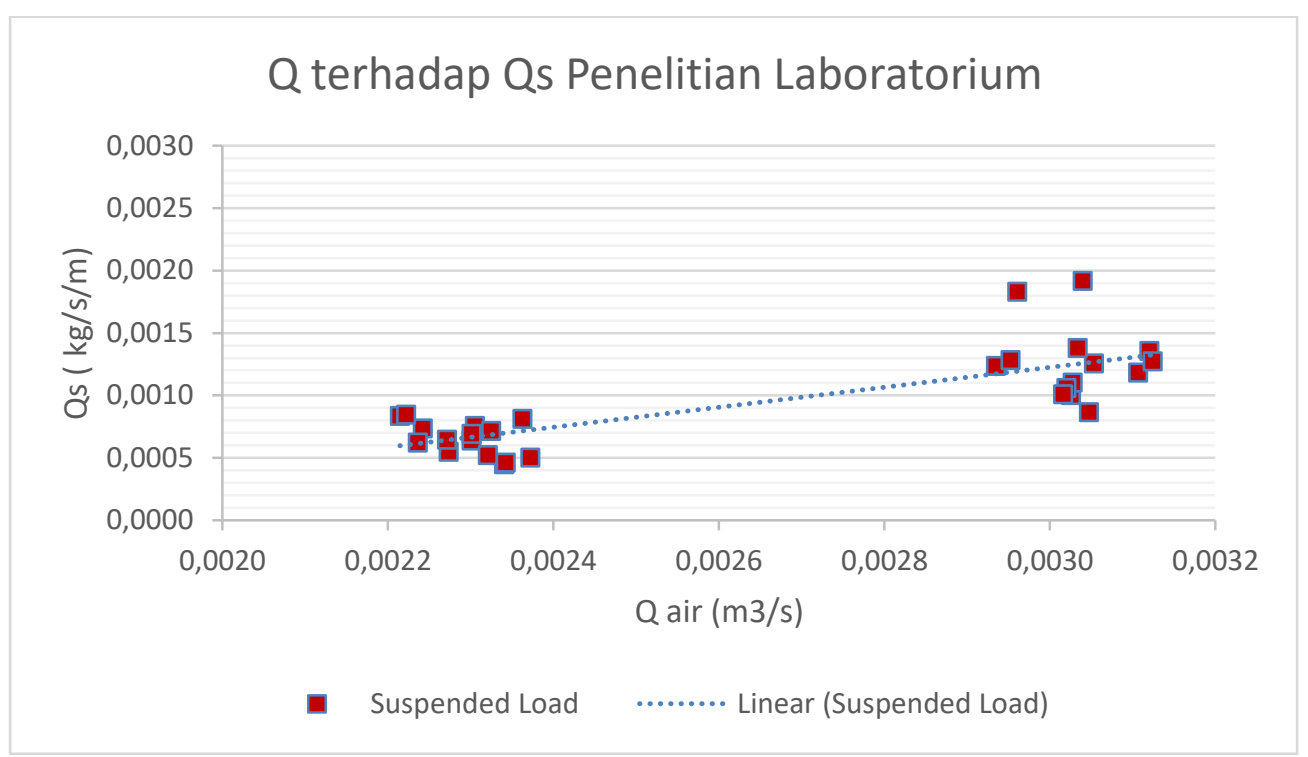

Gambar 7. Grafik Perbandingan Debit Air Terhadap Debit Angkutan Sedimen Melayang Laboratorium

\section{Analisis Debit Angkutan Sedimen Berdasarkan Pendekatan Einstein's}

Hasil analisa debit angkutan sedimen melayang dari pendekatan Einstein's dapat dilihat pada Gambar 8. 


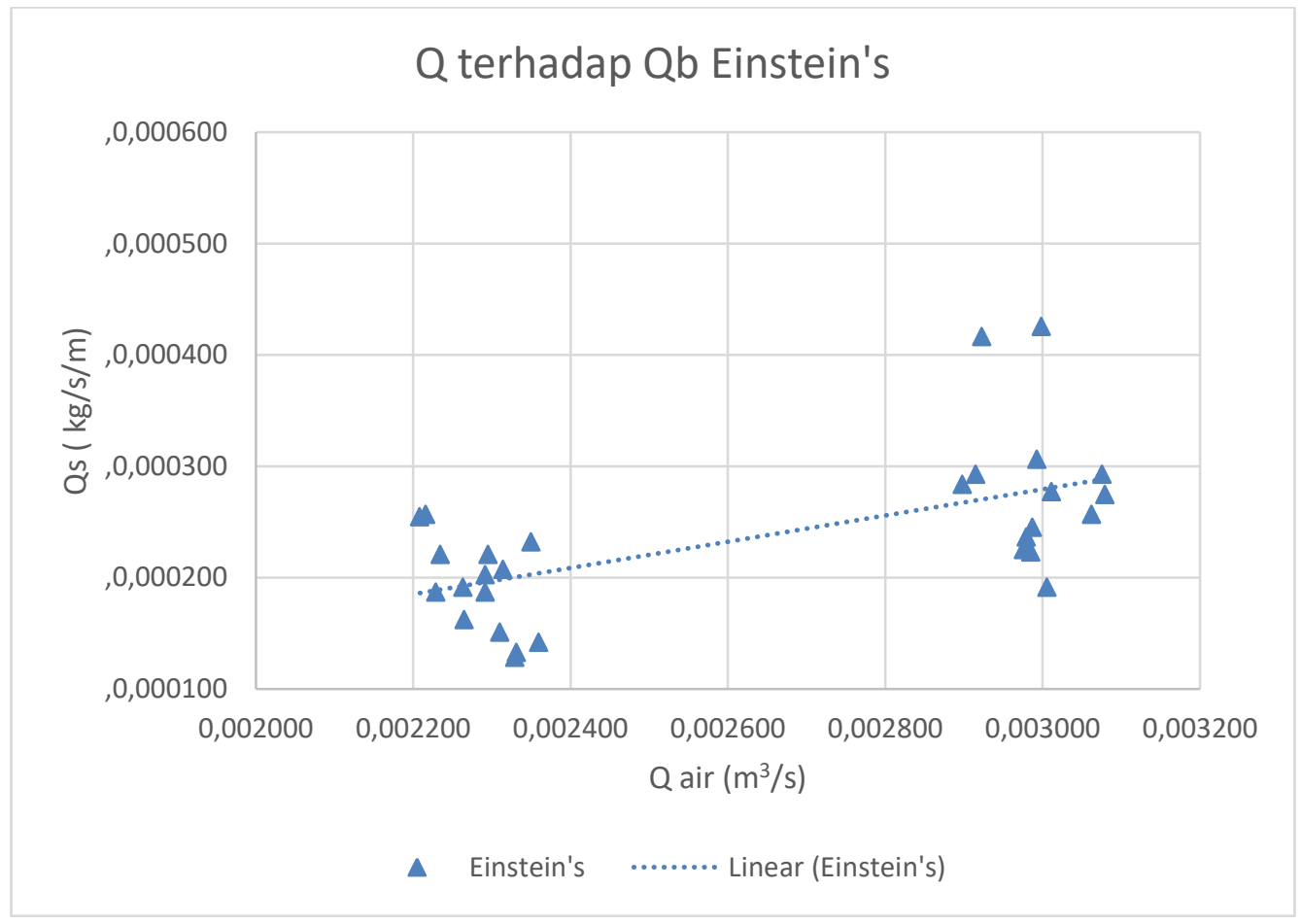

Gambar 8. Grafik Debit Air Terhadap Debit Angkutan Sedimen Melayang Einstein’s

\section{Analisis Debit Angkutan Sedimen Berdasarkan Pendekatan Lane dan Kalinske's} Gambar 9 .

Hasil analisa debit angkutan sedimen melayang dari Pendekatan Lane dan Kalinske's dapat dilihat pada

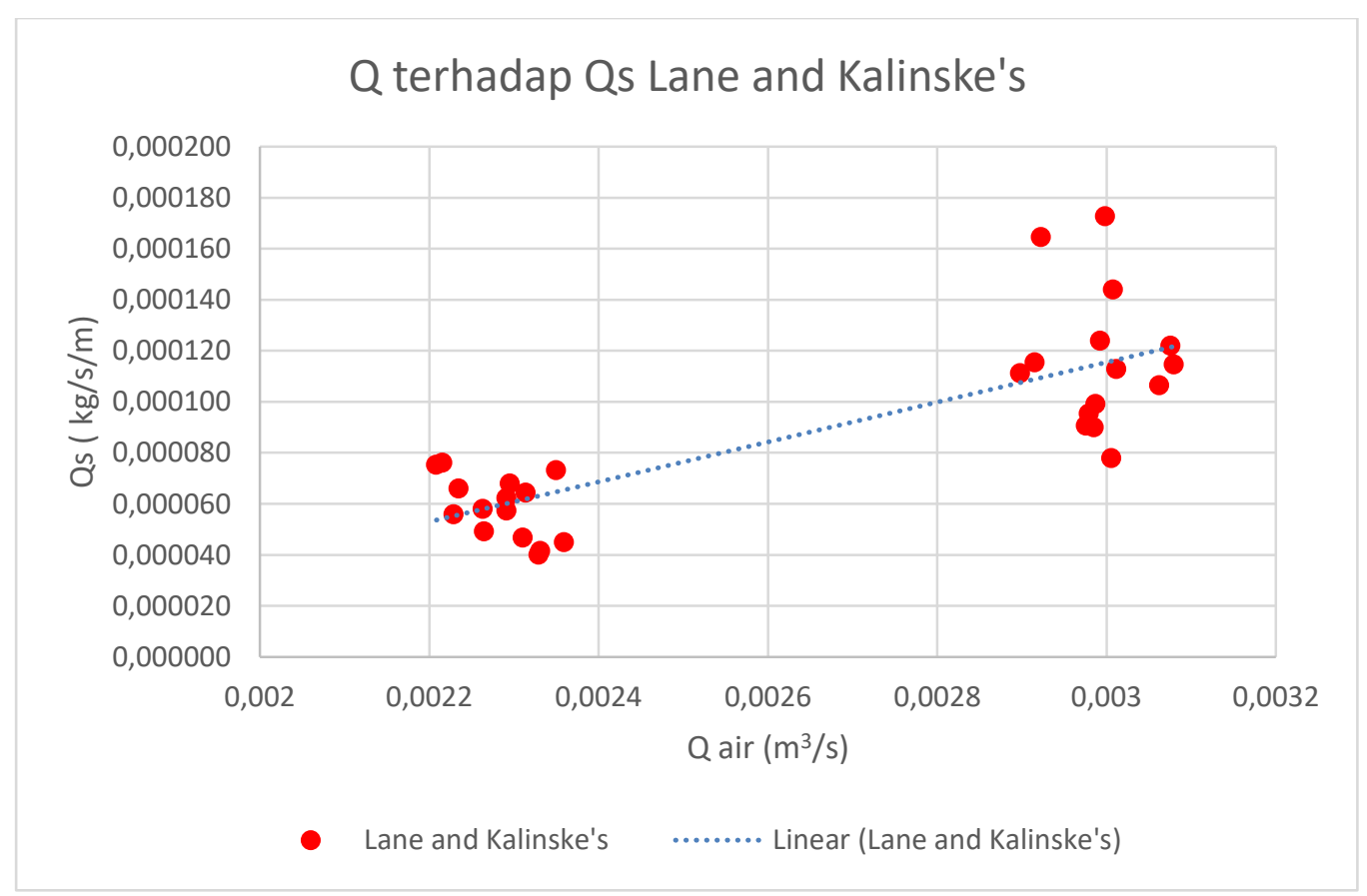

Gambar 9. Grafik Debit Air Terhadap Debit Angkutan Sedimen Melayang Lane dan Kalinske’s 


\section{Analisis Debit Angkutan Sedimen Berdasarkan Pendekatan Schoklitsch's}

Hasil analisa debit angkutan sedimen melayang dari Pendekatan Chang, Simon dan Richardson's dapat dilihat pada Gambar 10.

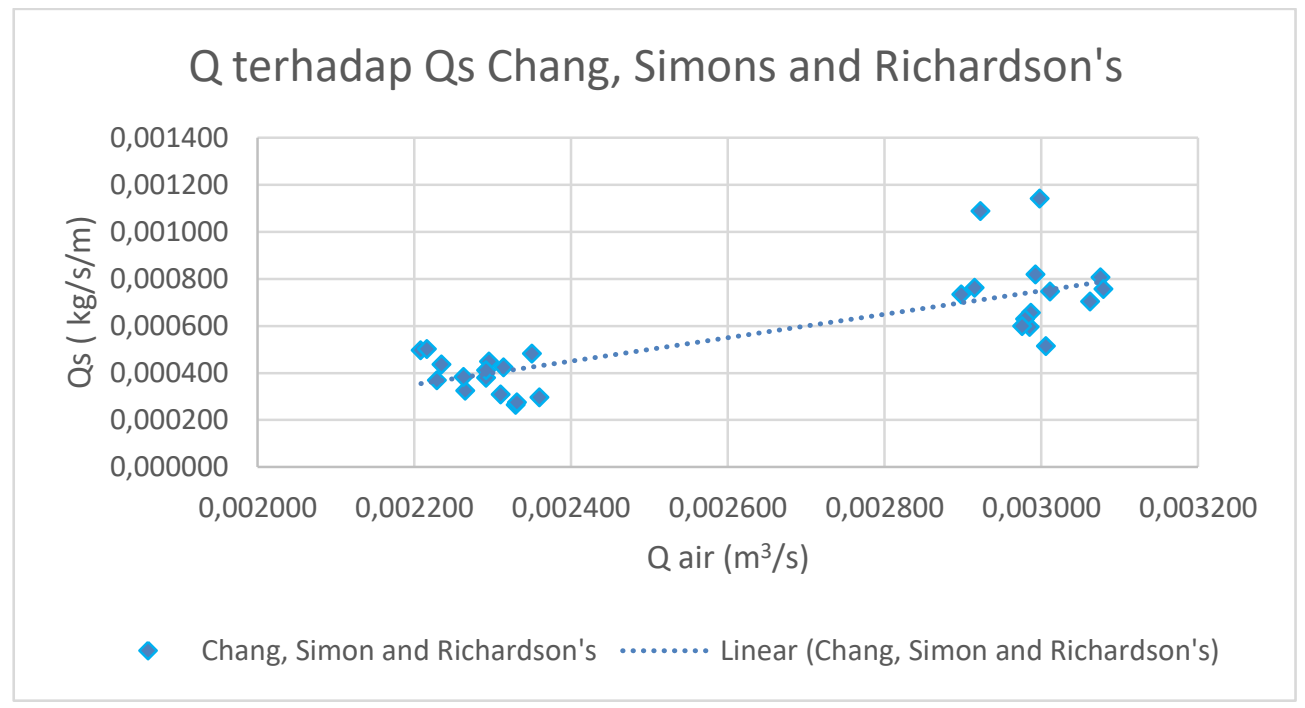

Gambar 10. Grafik Debit Air Terhadap Debit Angkutan Sedimen Melayang Chang, Simon dan Richardson's

\section{Perbandingan Hasil Laboratorium Dengan Pendekatan Rumus}

Rangkuman perbandingan hasil penelitian laboratorium dengan hasil pendekatan rumus dapat dilihat pada Gambar 11 .

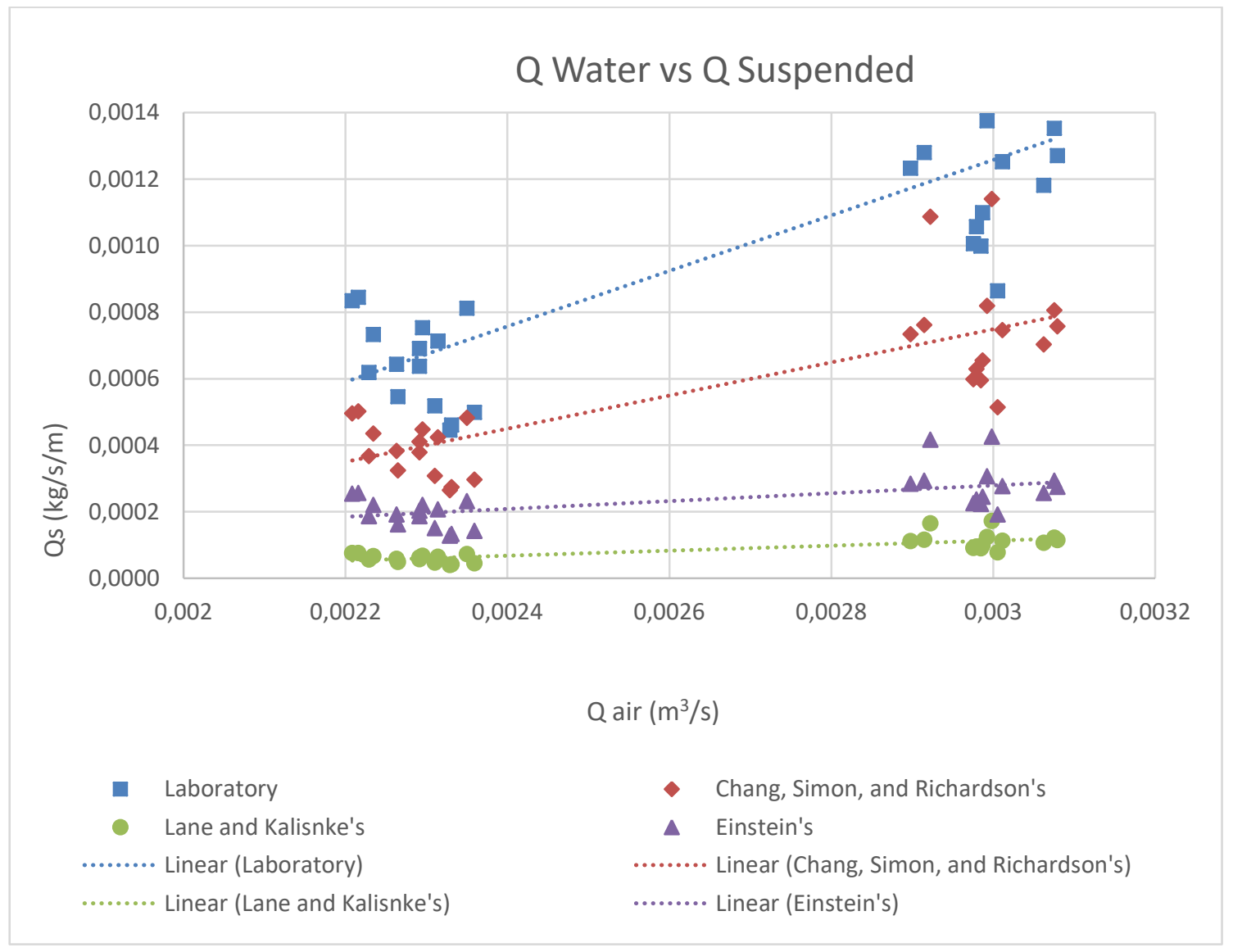

Gambar 11. Grafik Perbandingan Debit Angkutan Sedimen Melayang 


\section{KESIMPULAN}

Berdasarkan analisis yang dilakukan, didapatkan beberapa kesimpulan sebagai berikut:

1. Gradasi butiran sedimen Sungai Serayu yang paling banyak berkontribusi pada ukuran diameter 0,0316 mm karena sampelnya berupa lumpur.

2. Hasil percobaan laboratorium, dengan bertambahnya debit air maka partikel sedimen yang ikut bergerak dalam air akan ikut bertambah maka debit angkutan sedimennya juga semakin besar.

3. Hasil percobaan berdasarkan kedalaman, dengan bertambahnya kedalaman sampel maka kecepatan kritis yang diperlukan semakin besar, serta berat jenis basah dan berat jenis kering yang dihasilkan juga semakin besar.

4. Perbandingan debit angkutan sedimen malayang antara hasil laboratorium dengan hasil pendekatan rumus, maka pendekatan rumus Chang, Simon and Richardson's adalah yang paling mendakati hasil Laboratorium.

5. Persamaan Einstein's lebih didominasi oleh kecepatan geser sedimen serta tingkat kekasaran dari ukuran butiran, persamaan Lane and Kalinske's lebih dipengaruhi oleh konsentrasi sedimen yang melayang serta debit air dan persamaan Chang, Simon and Richardson's banyak terpengaruh dari besaran kecepatan aliran air.

6. Hasil percobaan Laboratorium, dengan besaran debit air $0,0022 \mathrm{~m}^{3} / \mathrm{s}-0.0031 \mathrm{~m}^{3} / \mathrm{s}$ diperoleh debit angkutan sedimen melayang $0.0004 \mathrm{~kg} / \mathrm{s} / \mathrm{m}-0.0019 \mathrm{~kg} / \mathrm{s} / \mathrm{m}$. Untuk persamaan Einstein's debit angkutan sedimen melayang 0.000128 - $0.000426 \mathrm{~kg} / \mathrm{s} / \mathrm{m}$, persamaan Lane dan Kalinske's 0.00004 - 0.000173 $\mathrm{kg} / \mathrm{s} / \mathrm{m}$ dan persamaan Chang, Simon dan Richardson's $0.000264-0.00114 \mathrm{~kg} / \mathrm{s} / \mathrm{m}$.

\section{DAFTAR PUSTAKA}

Diansari, R. (2014) “Analisis Perhitungan Muatan Sedimen (Suspended Load) pada Muara Sungai Lilin Kabupaten Musi - Banyuasin”, Jurnal Tenik Sipil dan Lingkungan Vol. 2, 225-230.

Pratiwi, Y. (2014) “Analisis Konsentrasi dan Laju Angkutan Sedimen Melayang pada Sungai Sebalo di Kecamatan Bengkayang”. PRISMA FISIKA, Vol. V, 99-105.

Profil Balai Besar Sungai Wilayah Serayu-Opak (2016), Direktorat Jendral Sumber Daya Air Departemen Pekerjaan Umum.

Sengupta, S.M. (1994) Intoduction to Sedimentology. Indian Institute Of Technology Kharagpur, India.

Sudira, I. W. (2013) “Analisis Angkutan Sedimen pada Sungai Mansahan”, Jurnal Ilmiah MEDIA ENGINEERING Vol.3, 54-57.

Wentworth C.K., (1992) “A Scale of Grade and Class Terms For Clastic Sediments”, Journal of Geology Vol. 30, 377-392. 